\title{
Gender and Access to Land Ownership: Christian Reflection on the Experience of Malawian Widows
}

\section{Gertrude A Kapuma ${ }^{1}$}

\begin{abstract}
${ }^{1}$ SHORT BIO
Gertrude Aopesyaga Kapuma is a senior Lecturer in the Department of Practical Theology at Zomba Theological College in Malawi. She is also an Ordained Minister in the Church of Central Africa Presbyterian (CCAP). Her research interests and publications focus on Pastoral Care and Counselling, Gender and Theology.
\end{abstract}

\section{INSTITUTIONAL AFFILIATION}

Department of Practical Theology at Zomba Theological College in Malawi; mbusaga@yahoo.com

ORCID

https://orcid.org/0000-0002-0776-0112

\begin{abstract}
Most women in Malawi encounter gender-based discrimination and violence when attempting to access land rights. Although legally land is transferred from parents to children, culturally in practical terms, land is either controlled by a brother or an uncle, leaving female members of the family with no decision-making powers. Upon the death of the husband, the widow loses property jointly held with the husband, as well as her own marital property to either the brother of the husband, or to her own brothers and uncles. Regardless of the many years spent in building their life together while enjoying the land they lived on and cared for together, unfortunately, the death of her husband leaves the widow with nothing. Lack of civic education makes many widows remain ignorant of the fact that the Malawian law protects them, and their land claims. This ignorance contributes to the suffering and impoverishment of many widows and leads some to live in acute poverty. The church has a special obligation to protect the rights of widows. It has an obligation to help empower women to secure land and the right to land so that widows can contribute to the larger community. Using a narrative approach, this article will demonstrate the difficulties faced by Malawian widows in terms of land claims. Current practices of inheritance and the ways widows are dispossessed will be uplifted through widows' own stories about their lived realities. The article will conclude by proffering constructive proposals about how the church can empower widows to find solutions to these very real problems.
\end{abstract}

KEYWORDS

Access to land, caring, Church, gender-based discrimination, violence, human rights, land ownership, Malawi, widows, Ubuntu.

\section{Introduction}

The right of women to own land in Malawi is not a straight forward issue. The majority of local people are largely dependent on subsistence farming for a living. Those who do not have land, hire land at a very expensive rate in order to grow food. Malawi has a population of 18 million people and most of them require a small piece of land for cultivation. The country has two systems of lineage, which are patrilineal and matrilineal. Both these systems, as well as practices within family life are influenced by patriarchy. 
In simple terms patriarchy is a system wherein men have authority over the household and women are expected to be subordinate to male power. When death strikes, male members of the family have the power to decide on funeral arrangements as well as distribution of the deceased's assets, particularly, land. Ruether defines patriarchy as "Rule of the father." She further elaborates that "patriarchy refers to a system of legal, social, economic, and political relations that validate and enforce the sovereignty of male heads of families over dependent persons in the household."1 In a society based on patriarchy, women experience systemic discrimination, their voices are not heard, and their interests are not being protected. Gruenbaum explains further that patriarchy is not only more power residing in men but that there is more to it:

Patriarchy is not simply a system of rule by males, but a more complex set of relationships that result in domination by older men over both younger men and females. However, there are other dominations and authorities here as well: females over children, older women over younger women, older children over younger children, boys as they grow up increasingly asserting themselves over girls, even older sisters who used to have authority, and so on. ${ }^{2}$

This is the context of Malawi in which land is controlled by men in families.

Culture has often been used to defend the treatment of those who are considered inferior in society. Culture is used against those that are powerless to benefit those in authority. The question that one could ask is: Does a healthy culture really oppress, discriminate and marginalise people? Women play a significant role in transmitting culture to their children, generation after generation. Through their given traditional roles, they are

Rosemary Radford Ruether, "Patriarchy," in Dictionary of Feminist Theologies, eds. Letty M. Russel, and Shannon. Clarkson, (Louisville: Westminster, 1996), 205.

2 Ellen Gruenbaum, Female Circumcision Controversy: An Anthropological Perspective. (Philadephia: University of Pennsylvania Press, 2001),378. 
able to teach their children the beliefs and traditional practices they hold. Kanyoro expresses her concern that:

Women in Africa are custodians of cultural practices. For generations, African women have guarded cultural prescriptions that are strictly governed by the fear of breaking taboos. ... Harmful traditional practices are passed on as 'cultural values' and therefore are not to be discussed, challenged or changed ... Such a state of affairs illustrates the reality of women's powerlessness and vulnerability in the face of cultural prescriptions. ${ }^{3}$

This kind of understanding of what culture is meant to be, affects the wellbeing of a widow. Culture is not static. Rather it is dynamic. So much has changed in our way of living except when it comes to patriarchal values that oppress women. Under the pretext of culture, people should stop treating widows as if they are less human. All other changes are accepted but when it comes to transforming the status of widows, culture is used as an excuse to deny her right to own land that could sustain her as she goes on with life. Such selective rigid attitudes raise two crucial questions: (1) Why do we make women victims of selfish cultural practices? (2) Should society not change the rights of land ownership so that women can benefit from it? To situate the context of these questions better, a discussion on Malawian cultural practices is necessary.

\section{Gender Context of Malawi vis a vis socio-economic and cultural practices in Malawi}

As indicated earlier, Malawi practices two cultural systems of lineage which are patrilineal and matrilineal. Each system has its own dynamics that impact the way people live. These dynamics often negatively affect women and, more so the widow.

3 Musimbi Kanyoro, "Engendered Communal Theology: African Women's Contribution to Theology in $21^{\text {st }}$ Century," in Talitha Cumi: Theologies of African Women, eds. Nyambura Njoronge and Musa W Dube (Pietermaritzburg: Cluster Publications, 2001), 159-160. 


\section{Patrilineal System}

This is practiced in the Northern region of Malawi and some districts in the Southern region. In patrilineal systems land is owned by the men. After marriage, women move to live in their husband's home. Men are decision makers and have the right to own land and children. Tschirhart et al explain that:

Women can only access land through their husbands and sons. ... Upon the death of the husband, the woman, as long as she is unmarried, can use the land her husband owned. As she grows old and as the sons grow old, she shares the land with her sons and may be squeezed out of the land. ${ }^{4}$

This means that after the death of her husband, the widow may us e the land as long as she is unmarried, but she may not own the property. She no longer owns the land, and if she is given land, she may be given that which is not fertile.

\section{Matrilineal System}

According to this system, land is passed on from parents to daughters. In matrilineal systems, when a woman gets married, her husband is expected to come and live with her in her home village. He is given a space by the uncle or brother of the woman to build his house. The wife in this marriage will make use of her own land inherited from her mother or from her grandmother. Even though she has the right to own land, some decisions are made by her uncle or brother as the mwini mbumba (custodian of the family clan). Even though she has these advantages, the husband is the head of the family and controls whatever happens to the proceeds of the farmland. This shows that the matrilineal system too has some shortfalls, and the woman, especially when widowed, may not have complete power

4 Naomi Tschirhart, Lucky Kabanga, and Sue Nichols, "The Convergence of HIVIAIDS and Customary Tenure on Women's Access to Land in Rural Malawi," Journal of Social Aspects of HIVIAIDS 12 no. 1 (2015): 134-146, 137. 
over her inheritance. Even the small piece of land that would sustain her is usually taken away from her.

Thus, in both systems-patrilineal and matrilineal-the people who are supposed to protect the woman are the same people who have the power to dispossess the widow, and cause hardship to her and her children. In such patriarchal family structures where power resides in the male family members, women become more vulnerable. The inability of such family systems to protect women leads to problems of gender-based violence. The widow becomes a victim of violence with no one to protect her. Le Roux comments that; "Challenging these patriarchal structures would mean challenging culture, as patriarchy is culturally supported and condoned." 5

If cultural practices are not challenged, women who are widows will continue to suffer and submit to dangerous rituals without questioning them.

The challenge is thus to find a way of challenging culture and the cultural practices which empower men at the expense of women, and which enable and leads to violence against women, while at the same time not denying or degrading the importance of culture. ${ }^{6}$

Most systems and structures in our society violate the rights of women (widows).

\section{Gender-Based Violence}

Violence targeted at women happens everywhere even in places like the home, where one would expect to get maximum security. Such violent behaviour is intended to show the other person that those in control have power and can do anything. It is also intended to undermine a person's humanity, identity and dignity. It encompasses acts of physical as well as

5 Elisabet le Roux, Telling Stories: Talking about VAW Within Church and Seminary," in Living with Dignity: African Perspectives on Gender Equality, eds. Elna Mouton, Gertrude Kapuma, Len Hansen, Thomas Togon. (Stellenbosch: Sun Press, 2015) 238.

6

Le Roux. Telling Stories, 239. 
emotional abuse. The dispossession of property which includes land, are acts of violence that affect the widow physically, emotionally, and psychologically. Zulu alludes to gender-based violence when he states that;

Despite the fact that this cultural practice applies to both men and women, it is in most instances the women who are subjected to it in practice. This is so because in most situations, the woman would be dependent on her husband for her livelihood. One also sees that this gender-based prejudice or treatment of women is linked with other culturally legitimised forms of discrimination- in some contexts, with a woman's inability to inherit from her husband, or women's inability to own land ... Men would often use her fellow women to subject her to all sorts of practices in the name of culture. ${ }^{7}$

Because the society is patriarchal in nature, and power resides in men, men will not risk challenging their own privileges to favour women. Patriarchy will make sure that men benefit at the expense of women, even if they do not deserve it.

Nyangweso comments that;

The major oral concern with regard to widowhood rites is that they violate many basic principles contained in all key International Human Rights Conventions. A culture that undermines one's health, freedom of choice and general welfare is a violation of the basic human rights and should be considered problematic. ${ }^{8}$

7 Edwin Zulu, "Masks and the Men Behind Them: Unmasking Culturally-Sanctioned Gender Inequality," in Living with Dignity: African Perspectives on Gender Equality, eds. Elna Mouton, Gertrude Kapuma, Len Hansen, and Thomas Togon. (Stellenbosch: Sun Press. 2015) 93.

8 Mary Nyangweso, "Religion, Human Rights, and the African Widow," Peace Human Rights Governance 1 no. 3 (2017): 374. 


\section{Poverty}

Poverty is a serious concern among women in Malawi. Women become poor due to many reasons such as being deprived of the basic necessities of life and being disadvantaged because of their marital or social status. Many widows live in poverty because all their possessions are taken away by their in-laws. In Malawi, the condition of poverty is manifested in the lack of a productive means to access basic needs of life such as food, water, shelter, health, and education. Widows are pushed to an unbearable plight when they are stripped of all they had and have no means to start a new life again. Everything may have been taken including land, which she could have cultivated in order to have food for survival. Sometimes the land she may have is a small piece that cannot produce anything without applying fertilizers and manure. These are the things she cannot afford because of her situation.

The experiences of some widows that make them to fall into this condition of poverty is not by choice but because family members do not take into consideration her upkeep in the long term. When her property is controlled, she becomes a victim of abuse. Chebet and Cherop further comment that;

Gendered poverty and the right to human dignity have been recognised as the central challenge to the development of humanity. Poverty is a dehumanising condition for everyone. It violates the human rights of the affected, whether women or men. Poverty subjects an individual to a state of powerlessness, hopelessness and a lack of self-esteem, confidence and integrity. ${ }^{9}$

9 Dorcas Chebet, Beatrice Cherop, "Gender and Poverty: Rereading Proverbs 31 in Pursuit of Social-economic Justice for women in the Reformed Church of East Africa," in Living with Dignity: African Perspectives on Gender Equality, eds. Elna Mouton, Gertrude Kapuma, Len Hansen, Thomas. Togon, (Stellenbosch: Sun Press, 2015), 195. 
This is a situation that some widows find themselves in as we will see from the stories later in this study that clearly portray that they have been victims of abuse.

\section{Land laws in Malawi with special reference to women:}

Summarising conclusions regarding property ownership and inheritance rights of women in her study ${ }^{10}$, Naomi Ngwira observes that because widows start from a low base of goodwill, they still inherit less often than men. Her study sets forth the following conclusions that show clearly the stark reality of dispossession faced by widows in Malawi. She says,

In the particular case of land, $37 \%$ of widowed respondents said that the husband relatives were among the heirs ... The fact that half of the respondents were from matrilineal customs and yet only $6 \%$ of widowers said that land devolves to the wife's relatives when she dies also poses a curiosity that needs to be further understood ... Since the administration and adjudication of inheritance is strongly influenced by perceptions, land may increasingly be owned by men even in matrilineal customs ... A logistic regression analysis (of) dispossession has shown that being a widow married according to patrilineal customs increases the odds of dispossession over being a widower married under the same customs, by 12.2 times. ...Property grabbing happened in $30 \%$ of the widows' cases compared to $3 \%$ for widowers. Thus, the likelihood of a widow's inheritance being grabbed is 10 times that of a widower. Grabbing may be a remnant of traditional customs of sharing out all the property, except kitchen items, usually under the pretext that everybody needs some of the property to wipe away their tears.

10 Naomi Ngwira, "Women's Property and Inheritance Rights and the Land Reform Process in Malawi" (Development Alternatives Inc, and USAID, Year NA), accessed July 27, 2021, https://sarpn.org/documents/d0000585/P522_Malawi_property_rights.pdf 
It is such a context that the Malawian Land Policy reforms tried to address since the turn of the millennium. According to a Working Paper on securing land rights for women in Malawi put together by Netherlands Land Academy (LANDac) and Oxfam in Malawi, ${ }^{11}$ the Malawi National Land Policy (2002) mentions the rights of 'vulnerable' groups, including women, children and the disabled, and stresses the need for a clear policy and implementation strategy to ensure equal rights and access for women and men. ${ }^{12}$ Subsequently land bills for better tenure security were passed in 2016 and the new Land Bill came into force in March 2018. These new Land Policies state that customary land committees shall be responsible for the management of all customary land in a Traditional Land Management Area and that at least two out of six committee members should be women. ${ }^{13}$

However, despite these legal advances, many women are still denied the right to own property due to practices that discriminate against them. ${ }^{14}$ The problem is exacerbated by low literacy levels among women and a high child marriage rate. ${ }^{15}$ In 2018, after the 2018 land laws had been passed, Jean Kalilani, Minister of Gender, Children, Disability and Social welfare, summed up the stark situation of widows in Malawi when she said: "We have seen cases of women going destitute following the death of their husband just

11 Oxfam in Malawi and LANDac, "Securing Women's Land Rights: Scaling for Impact in Malawi," Working Paper 4: Securing Women's Land Rights in Africa. (Utrecht: LANDac.,2018) accessed July 27, 2021, http://www.landgovernance.org/assets/20181127-

A4-Working-paper-04_Malawi.pdf, 2

12 Oxfam in Malawi and LANDac, Working Paper 4, 2.

13 Clause 14 and Clause 25 (f) of Customary Land Regulations 2018, Malawi Gazette Supplement, dated 20th April, 2018, containing Regulations, Rules, etc. (No. 9A), Government Notice No. 18, (Lilongwe, Malawi: The Government Printer, 2018), accessed July 27, 2021, https://resourceequity.org/record/3152-malawi-customary-land-regulations/

14 Emma Kaliya, Head of the Gender Coordination Network, as quoted by Madalitso Kateta, "Malawian Women Struggle for Land Rights Despite Equality Drive," Thomson Reuters Foundation, September 25, 2018, accessed July 27, 2021, https://www.reuters.com/article/us-malawi-landrights-women-idUSKCN1M51GQ

15 Lucky Kabanga, a researcher at SAHARA-J, a journal as quoted by Madalitso Kateta, "Malawian women Struggle for Land Rights." 
because they lost most of the property to their spouse's relatives." 16 She further affirmed that the government was committed to protecting such women through enabling laws.

The (LANDac) and Oxfam Working Paper highlights some pertinent strategies to ensure that provisions in the new Land Policy are taken forward with regard to omen's land rights, land registration and opportunities for women: ${ }^{17}$ 1) Take measures to ensure women attend meetings called by the chiefs regarding customary land registration and titling. Only then women can be available to participate in the elections so that they can become members of customary land committees. Women being elected members will ensure that the chiefs do not take bribes or intimidate women. ${ }^{18} 2$ ) Mobilise women leaders to act as local champions and to demand their position on either customary land committees or the customary land tribunal, and to be protectors of women rights in the traditional authority of the village. 3 ) In general, raise the awareness of grassroot women about the new Land Policies, including the new 2016 land bills. 4) Consistently Keep engaging traditional leaders (who are gatekeepers for their communities) and mobilising them to advocate for women's land rights in the country.

The broad gender context of Malawi and the laws pertaining to property, inheritance and land rights of women in Malawi provide the backdrop in which the narratives of widows dispossessed of their property and lands should be properly situated. Having thus situated the context, this study next applies a narrative methodology to uplift the voices of widows and their experiences of dispossession.

16 Madalitso Kateta, "Malawian Women Struggle for Land Rights Despite Equality Drive," Thomson Reuters Foundation, September 25, 2018, accessed July 27, 2021, https://www.reuters.com/article/us-malawi-landrights-women-idUSKCN1M51GQ

17 Oxfam in Malawi and LANDac, Working Paper 4, 4-5.

18 Oxfam in Malawi and LANDac, Working Paper 4, 4. 


\section{Giving voice to the widows}

In order to understand in-depth, the plight of widows and the violence they experience in their quest to own land, the author has used a narrative approach. This method was chosen to allow widows to narrate their stories thereby providing authentic data for analysis. Kumar confirms that: "Narratives are very powerful method of data collection for the situations which are sensitive in nature"19. A purposeful sampling was done with two groups of women - one from the urban and another from semi-rural areas. Through sharing of their sacred stories widows were able to learn from each other's situations and this was immensely helpful. Few widows who were interviewed expressed disappointment at the way they were treated after the death of their husbands. They could share their painful experiences as they narrated their stories. Almost all the widows were emotionally wounded because of the lack of support even from people they trusted. In order to protect their identities, the author will use different alphabet to represent them instead of their names.

Widow K said that:

I went to live in my late husband's home. I took care of his children from another relationship and his mother who was blind. After the burial of my husband in 2012, they wanted me to go to my village immediately, but because of the sick mother in-law, I resisted. I felt that I had an obligation to look after her, besides there was no one to care for her. When she died, my late husband's family started illtreating me. They burnt the house I was living, took the property, and would steal whatever I had. They did this to make sure that I leave. I went home with nothing; my family received me and gave me a space to build a house. I hire a piece of land every year to cultivate because all the land in my family is taken by my sisters and cousins. We had a

19 Ranjit Kumar, Research Methodology: A Step -by-Step guide to Beginners, (London: Sage, 2005), 125. 
good fertile land at my husband's home, all that was taken away from me and shared amongst my husband's nephews and nieces. ${ }^{20}$

The outcry of most of the widows relates to how the property and land was taken away from them. In some cases, the widows were left with nothing to start a new life. They are left with nothing to help support care of their children.

Widowhood experience was described as inhuman. Widow $\mathrm{G}$ narrated her story thus:

My husband was diagnosed with kidney failure and died in 2015. The family took all the six houses we were letting out. They took all the money benefits that came. They also sold the land that belonged to us. I was left with nothing. I could not send my son to school because there was no money to pay for his fees. Thinking about the life we had before and the hardships that we were going through, my son attempted to commit suicide. This happened when he was selected to go to secondary school and there was not enough money to pay for his school fees. It was a difficult situation coming from a 'somebody' to a nobody. I have no relationship with them. I was a respectable person when their son (my husband) was alive, but when he closed his eyes (died), they did what suited them. ${ }^{21}$

The story above illustrates clearly how women's rights are violated with impunity and it is taken for granted that the widows will abide with such violation of their rights. Chitando explicates how this needs to be challenged when he says,

20 Widow K (not real name), Interviewed in September, 2017 in Zomba. These are women coming from the Women's Guild in the Church who felt that the Church was not there to help them.

21 Widow G (not real name) Interviewed in September, 2017 in Zomba. 
Personhood in African cultures has been construed and constructed in a hierarchical manner, with men enjoying full and privileged status ... Expunged of its patriarchal underpinnings, ubuntu can socialise boys and men to fight sexual and gender-based violence. Currently African men committing violence are not exuding ubuntu (particularly in its refined form). Ubuntu can empower men to realise and accept the full humanity of women. ${ }^{22}$

When men are empowered to understand issues of violence, oppression, and dehumanisation faced by women, they will begin to affirm and protect women and afford them the dignity they deserve.

Many widows are not aware of the laws that are in place in the country laws that can protect them from being dispossessed. Widow B described that:

They wanted the bank book immediately after the funeral in 2014. I refused to give them. They went and took control of the Guest House that we had as a business, and one piece of garden, which was more fertile. We had nothing to live on except for the small garden. ${ }^{23}$

Women need protection. This protection may not be available from her family or community where she lives. The community leadership including the church should make themselves available to assist and journey with the widow. Nyangweso propounds that;

Although indigenous practices and attitudes are culturally legitimate and meaningful in social units in which they are found, it is imperative that moral principles remain a fundamental responsibility of Africans. Recognizing that some of what is upheld, as culture is incompatible

22 Ezra Chitando, "Do Not Tell the Person Carrying You that S/he Stinks: Reflection in Ubuntu and Masculinities in the Context of Sexual Gender-based Violence and HIV," in Living with Dignity: African Perspectives on Gender Equality, eds. Elna Mouton, Gertrude Kapuma, Len Hansen, Thomas Togon, (Stellenbosch: Sun Press 2015), 276.

Widow B. Interviewed in September, 2017 in Zomba. 
with the welfare of significant members of African communities, ought to be central to efforts to promote human rights in Africa. It is particularly important that the rights of women be centralized in moral discourse of African virtues." 24

Widow $\mathrm{P}$ also narrated with bitterness her experiences in interacting with her in-laws in the following words:

When my husband retired from work, we agreed to come and settle at his home. We bought land not far from the family home. We developed the place and the land. When he died in 2010, my in-laws wanted me to go back to my home. I asked them, 'where will I go? I have been here for a long time; my people do not know me. I have my children and grandchildren here, I cannot leave.' They decided to do the last ritual so that I could go back home. They were doing this because they wanted the land that we had developed. They felt that I did not deserve to own the good land since I was not biologically connected to their family. They forgot the time I spent to develop the land and make the home good. They wanted all that. I refused. In 2014, they took me to the Village Chief so that he could agree that I go back home. I was accused of not wanting to leave my husband's land to his people because I was a witch; that I wanted to stay in the village to kill the people. ${ }^{25}$

Such inhuman treatment and exploitation come coated in the name of culture. The community takes it for granted that the widow is going through her grieving period without problems and choose not to pay attention to the pain she is going through which needs attention and care.

Women are supposed to live with dignity as those created in the image of God. They are supposed to be treated as human beings who have rights. Whenever one makes reference to African culture, it is pertinent that one

24 Nyangweso, "Religion, Human Rights, and the African Widow," 387.

25 Widow P. Interviewed in September, 2017. 
takes cognisance of the fact that culture is not static but dynamic. Cultural practices have to change with time. Women have to be recognised as people with their own rights to exist with dignity and happiness. Baloyi further comments that:

Cultural widowhood rituals clash with the rights of individuals involved in the act. Despite the widow's tears, many African women continue to instigate this practice even if it threatens someone's life. A culture that disregards one side of human individual rights but promotes the other fails to acknowledge what it means for God to have created a human being as complete. It fails to recognise that human individual rights are essential steps towards reaching full development for women. ${ }^{26}$

When the full humanhood of women and their rights are observed and women themselves know their rights, they will be able to go to the right places to seek advice. This knowledge on human rights and the laws relating to land and property should also be imparted to the custodian of culture, for instance, the Village Chiefs so that they can understand and protect the interests of women.

In light of the above discussion, it is evident that culture should change with time and while there is a need to look at the positive elements of culture that make us who we are, there is a greater need to abolish those practices that are inhuman and dangerous to women. This is the hope is for all communities, and that includes the church as well, to bring back ubuntu.

A discussion on cultural anthropology will ground an analysis of systems and structures that are oppressive to women.

26 Gift Baloyi, "When Culture Clashes with Individual Human Rights: A Practical Theological Reflection on the Dignity of Widows. Verbum et Ecclesia 38, no. 1 (2017): 1-5. 


\section{Cultural Anthropology}

According to the Dictionary of Feminist Theology, Lummis explains that, "Cultural anthropology is the study of cultures of various groups over time and how their values and beliefs interrelate and change." 27 Some cultural beliefs have changed with time but there are still some that resist change. This is so because of the socialization process that people go through makes them think that cultural beliefs are the accepted norm.

Parents, especially the mother, play an important role in the upbringing of children. There are basics and life skills that children learn from their mothers. These basic life skills and knowledge are common to all children regardless of gender. But in many cases, the female child experiences discrimination and is expected to learn more life skills than the boy child. Society regards men as strong and women as weak, and although this may be portrayed as positive as the girl child acquires more life skills, in actual fact, this disguises the reality that the girl child is conditioned to be submissive and the boy child to be in control. A boy child can control even the older sisters and make them do things for him. The male child sees himself to be as important as the father and as compared to the mother and sister. He can also have authority in the home in the absence of the father. Women are expected to play by all these values. "These values that are instilled in girls include being submissive and subservient to men in the family. This leaves them disempowered and without 'skill' to escape violent situations or relationships." ${ }^{28}$ In-laws will be eyeing their land and sometimes a brother of the deceased would also want access the land because it is productive and consequently this prevents the widow from owning it. The bottom line that cultural belief upholds is that if you are a woman, you may not control property and access land freely, and that a male relative has the prerogative to decide on issues of land and property. Women thus, live

27 Adair Lummis, Anthropology, Cultural, in Dictionary of Feminist Theologies, eds. Letty Russell, and Shannon Clarkson, (Louisville: Westminster, 1996), 9.

28 Gertrude Kapuma, Gender Based Violence and the Church? Malawian Women Speaking Out, in Living with Dignity: African Perspectives on Gender Equality, eds. Elna Mouton, Gertrude Kapuma, Len Hansen, Thomas Togon, (Stellenbosch: Sun Press 2015), 257. 
without security. All of this suffering of women is justified on the pretext of protecting our cultural values and beliefs.

Oduyoye outlines what women's anthropology is by looking at what culture prescribes for women. She argues that;

Women's anthropology points out that what is described as feminine and masculine are culture-coded and should not be allowed to circumscribe our humanness. It is, therefore, unacceptable that women's humanness should be limited to biology and that the cultures that make women into beings whose only reason for existence is to assure the continuity of the race need to be transformed. ${ }^{29}$

This mind-set may be one of the reasons why widows are unable to contribute to their own and their children's socio-economic well-being. Cultural beliefs determining access to land to grow crops that can assist the family disempowers women.

Human dignity is essential if we are to live a fulfilled life. Women have a right to enjoy their humanness. The widow status should not be seen as a basis for treating them as if they are nothing and that they do not belong to the family. They have a right to continue the life they built with their husbands and take care of their children with dignity and be able to provide for the children. Widows need to have and experience the abundance of life that was promised by Jesus. That is why Oduyoye says:

Women are seeking to pursue an anthropology that makes women and men co-responsible for the well-being of the whole community especially the family ... And the man ought to recognize his coresponsibility genetically, and in the upbringing of the children he participates in making. ${ }^{30}$

29 Mercy A Oduyoye, Introducing African Women's Theology, (Sheffield: SheffieldAcademic Press, 2001), 70.

30 Oduyoye, Introducing African Women's Theology, 72. 
Taking a cue from women's anthropology therefore implies that in affirming women, widows will have power to exercise and own property including land. There should be ways to help restore the dignity of women so that they may live a life that has meaning. What this means is that culture, which is oppressive and exploits people, in this case, women, cannot be accepted. The enabling nature of Malawian land laws related to women and the possible strategies to implement them are issues that the church and faithbased communities could get involved in through church and community mobilisation, both to raise awareness and provide solidarity to women lobbying for these rights. Issues of violence should be the priority of each community including the church because it deals with the humanity of people and as it is a justice issue.

\section{Role of the Church}

The Bible is clear in its teachings pertaining to loving and caring for others. This is the fundamental basis of Christian beliefs and practice. God loves and cares for all creation and this includes women created in the divine image (Gen. 1:27). God does not only love and care for widows, but God is also the defender of the widows so that they should not experience shame. Psalm 68:1 says, "A father to the fathers, a defender of widows, is God in his holy dwelling (NIV). God is a God of justice and compassion. This is the basis that the Christian tradition must use in dealing with issues of injustice and exploitation. Issues of women should be handled with dignity because they are justice issues. The Christian tradition must bring back the lost biblical vision of the duty it owes to widows. In the present age this includes fighting for widows to have what belongs to them including land.

The church is the body of Christ called to care for God's people and bring human dignity to all. The church is seen as a safe place where people can go to without being harmed or discriminated against. Holmes et al says: "We; as a faith community, can be the safe place that people are intuitively 
searching for." 31 Unfortunately, the faith community has been too slow to offer such support. She has allowed culture to control the well-being of its members, consequently making them to suffer. Shisanya points out that the absence of the church in the face of women's struggles has made her unable to address some of the critical issues that affect widows. She comments that; "The Church as a major liberating agent should show practical commitment to the oppressed and work for their fruitful future." 32 In this regard, the community of faith needs to be liberated in order to liberate others.

The community of believers must be Christ like - to love and care for all people. Holmes and Williams add: "What we are describing here is more than just a polite, smiley kind of love. Christ suggests that we are all capable of loving one another as an act of human will, hence his command to love (Lk. 10:27)." ${ }^{33}$

Culture should not be used as a tool to oppress people. Both men and women should be able to understand culture in the light of Christ so that they become liberated. Jordaan and Mpumlwana add:

I do not mind a cultural practice if it does not contribute to the belittling of women. Once people exploit, discriminate against, and deprive women of their God given status, in the name of culture, I begin to have a problem as a Christian. ${ }^{34}$

Baloyi affirms that:

Total freedom for women cannot be fully attained when inhumane cultural practises are still prevalent. Most cultural rituals release males

31 Peter Holmes and Susan Williams, Church as a Safe Place: A Handbook Confronting, Resolving and Minimizing Abuse in the Church, (Colorado Springs: Authentic. 2007), 13. Constance Shisanya, Death Rituals, in Groaning in Faith: African Women in the Household of God, eds. Musimbi Kanyoro and Nyambura Njoroge, (Nairobi: Action, 1996), 186-194. Peter Holmes and Susan Williams, Church as a Safe Place, 17.

34 Roxanne Jordaan, and Thoko Mpumlwana, "Two Voices from Women's Oppression and Struggle in South Africa, in Feminist Theology from the Third World: A Reader, ed. Ursula King. (London: SPCK 1994), 165. 
from their control and leave women to suffer. Such cultural hegemonies should not be worshipped as if they have been prescribed by a higher authority and cannot be changed. Culture is dynamic, and as such is changeable. ${ }^{35}$

Issues of gender-based violence should be included in the curriculum in theological institutions so that students understand how these issues negatively affect women in the community, and are empowered to address them positively when they go to work in the congregations. Lay training institutions and theological education by extension should also address these social issues and produce learning materials for the grassroots church. Such materials and knowledge will empower the communities to live in harmony with women, and respect one another's rights.

\section{Conclusion}

In conclusion, women as citizens of Malawi as well as members of faith communities have the right to own land. Access to land will help women and widows become independent and live with freedom. The Christian tradition should rediscover its voice as a liberating agent, and an agent of positive cultural reinforcement (Ubuntu) that challenges cultural injustice. For this to take place, the leaders of the community, including the faith-based organizations, and the civil society, have a role to educate members on issues that affect the community such as inheritance rights and equitable land distribution. Faith communities must be transformed to become healing and holistic spaces for everyone. It should demonstrate the Christ like love to all members including women, and especially widows, so that all are able to experience the abundance of life promised by Jesus. When women, including widows are denied access to land, they are being denied access to live in abundance which is a human right. The church should become a prophetic presence to ensure that women are treated with dignity and empowered to rise out of poverty, and this role of the church can be

35 Baloyi, "When Culture Clashes" 1-5. 2. 
practically manifested in the rooting out of practices that result in land grabbing, gender-based violence and human rights abuses.

\section{References}

Baloyi, Gift. "When Culture Clashes with Individual Human Rights": A Practical Theological Reflection on the Dignity of Widows." Verbum et Ecclesia 38, no 1 (2017): 1-5.

Chebet, Dorcas, and Cherop, Beatrice. "Gender and Poverty: Rereading Proverbs 31 in Pursuit of Social-economic Justice for Women in the Reformed Church of East Africa". In Living with Dignity: African Perspectives on Gender Equality, edited by Elna. Mouton, Gertrude Kapuma, Len Hansen, Thomas Togon. 193-218. Stellenbosch: Sun Press. 2015.

Chitando, Ezra. "Do Not Tell the Person Carrying You that S/he Stinks": Reflection in Ubuntu and Masculinities in the Context of Sexual Genderbased Violence and HIV." In Living with Dignity: African Perspectives on Gender Equality, edited by Elna Mouton, Gertrude Kapuma, Len Hansen, Thomas Togon. 269-283. Stellenbosch: Sun Press, 2015.

Customary Land Regulations 2018, Malawi Gazette Supplement. Malawi: Lilongwe, The Government Printer, 2018. Accessed July 27, 2021. https://resourceequity.org/record/3152-malawi-customary-land-regulations/.

Gruenbaum, Ellen. Female Circumcision Controversy: An Anthropological Perspective. Philadephia: University of Pennsylvania Press, 2001.

Holmes, Peter and Williams, Susan, Church as a Safe Place: A Handbook Confronting, Resolving and Minimizing Abuse in the Church. Colorado Springs: Authentic, 2007.

Jordaan, Roxanne and Mpumlwana, Thoko. "Two Voices from Women's Oppression and Struggle in South Africa". In Feminist Theology from the Third World: A Reader, edited by. Ursula King, 150-167. London: SPCK, 1994. 
Kanyoro, Musimbi. "Engendered Communal Theology: African Women's Contribution to Theology in $21^{\text {st }}$ Century." In Talitha Cumi: Theologies of African Women edited by Nyambura Njoronge, and Musa Dube,159-160. Pietermaritzburg: Cluster Publications, 2001. 159-160.

Kapuma, Gertrude, "Gender Based Violence and the Church? Malawian Women Speaking Out". In Living with Dignity: African Perspectives on Gender Equality, edited by Elna Mouton, Gertrude Kapuma, Len Hansen and Thomas Togon, 253-268. Stellenbosch: Sun Press, 2015.

Kateta, Madalitso, "Malawian Women Struggle for Land Rights Despite Equality Drive." Reuters, September 25, 2018. Thomas Reuters Foundation. https://www.reuters.com/article/us-malawi-landrights-womenidUSKCN1M51GQ.

Kumar, Ranjit, Research Methodology: A Step-by-Step guide to Beginners. London: Sage, 2005.

le Roux, Elisabet. "'Telling Stories"': Talking about VAW Within Church and Seminary". In Living with Dignity: African Perspectives on Gender Equality, edited by Elna Mouton, Gertrude Kapuma, Len Hansen, Thomas Togon. 235-252, Stellenbosch: Sun Press, 2015.

Lummis, Adair. "Cultural Anthropology." In Dictionary of Feminist Theologies edited by

Letty M. Russel and Shannon Clarkson, 205-206. Louisville: Westminster, 1996.

Ngwira, Naomi. "Women's Property and Inheritance Rights and the Land Reform Process in Malawi." Accessed July 27, 2021. https://sarpn.org/documents/d0000585/P522 Malawi property rights.pdf

Nyangweso, Mary. Religion, Human Rights, and the African Widow. Peace Human Rights Governance, 1 No3. (2017): 65-391. 
Oduyoye, Mercy Amba. Introducing African Women's Theology. Sheffield: Sheffield Academic Press, 2001.

Oxfam in Malawi and LANDac, "Securing Women's Land Rights: Scaling for Impact in Malawi." In Working Paper 4: Securing Women's Land Rights in Africa. Utrecht: LANDac.,2018. Accessed July 27, 2021, http://www.landgovernance.org/assets/20181127-A4-Working-paper04 Malawi.pdf.

Ruether, Rosemary Raddford. "Patriarchy." In Dictionary of Feminist Theologies edited by Letty M.

Russel and Shannon Clarkson, 205-206. Louisville: Westminster, 1996.

Shisanya, Constance. "Death Rituals". In Groaning in Faith: African Women in the Household of God, edited by Musimbi Kanyoro and Nyambura Njoroge,186-194. Nairobi: Action, 1996.

Tschirhart, Naomi, Kabanga, Lucky, and Nichols, Sue, "The Convergence of HIVIAIDS and Customary Tenure on Women's Access to Land in Rural Malawi." Journal of Social Aspects of HIVIAIDS. 12 no. 1 (2016): 134-146.

Zulu, Edwin. "Masks and the Men Behind Them: Unmasking Culturally Sanctioned Gender Inequality.". In Living with Dignity: African Perspectives on Gender Equality, edited by Elna Mouton, Gertrude Kapuma, Len Hansen, and Thomas Togon, 81-95. Stellenbosch: Sun Press, 2015. 